\title{
Mixed Agonist-Antagonist Properties of Clozapine at Different Human Cloned Muscarinic Receptor Subtypes Expressed in Chinese Hamster Ovary Cells
}

\author{
Maria C. Olianas, Ph.D., Carlo Maullu, Ph.D., and Pierluigi Onali, M.D.
}

We recently reported that clozapine behaves as a partial agonist at the cloned human $m 4$ muscarinic receptor subtype. In the present study, we investigated whether the drug could elicit similar effects at the cloned human m1, $m 2$, and $m 3$ muscarinic receptor subtypes expressed in the Chinese hamster ovary $(\mathrm{CHO})$ cells. Clozapine elicited a concentration-dependent stimulation of $\left[{ }^{3} \mathrm{H}\right]$ inositol phosphates accumulation in $\mathrm{CHO}$ cells expressing either the $m 1$ or the $m 3$ receptor subtype. Moreover, clozapine inhibited forskolin-stimulated cyclic AMP accumulation and enhanced $\left[{ }^{35} S\right]$ GTP $\gamma S$ binding to membrane $G$ proteins in $\mathrm{CHO}$ cells expressing the $m 2$ receptor. These agonist effects of clozapine were antagonized by atropine. The intrinsic activity of clozapine was lower than that of the full cholinergic agonist carbachol, and, when the compounds were combined, clozapine potently reduced the receptor responses to carbachol. These data indicate that clozapine behaves as a partial agonist at different muscarinic receptor subtypes and may provide new hints for understanding the receptor mechanisms underlying the antipsychotic efficacy of the drug.

[Neuropsychopharmacology 20:263-270, 1999] (C) 1999 American College of Neuropsychopharmacology. Published by Elsevier Science Inc.
KEY WORDS: Clozapine; Atropine; Human muscarinic receptor subtypes; Second messengers; Receptor binding; $\left[{ }^{35} \mathrm{~S}\right] \mathrm{GTP} \gamma \mathrm{S}$ Binding; Chinese hamster ovary cells

The atypical antipsychotic drug clozapine has long been known to bind with high affinity to acetylcholine muscarinic receptors (Miller and Hiley 1974; Snyder et al. 1974). However, the results concerning the pharmacological activity of clozapine at these receptors are controversial. A number of studies performed either in vivo or in vitro have reported that clozapine behaves as

From the Section on Biochemical Pharmacology, Department of Neurosciences (MCO, PO) and the Department of Medical Sciences (CM), University of Cagliari, Cagliari, Italy.

Address correspondence to: Pierluigi Onali, M.D., Section on Biochemical Pharmacology, Department of Neurosciences, University of Cagliari, via Porcell 4, 09124 Cagliari, Italy.

Received 15 January 1998; revised 27 April 1998; accepted 8 May 1998. a muscarinic receptor antagonist. Thus, clozapine has been found to antagonize oxotremorine-induced tremors and physostigmine-induced mortality in mice and rats (Fjalland et al. 1977; Sayers and Burki 1976; Niemegeers et al. 1982) and to block the crayfish hindgut contraction and cat hippocampal cell excitation elicited by cholinergic agonists (Herrling and Misbach-Lesenne 1982). In rat striatum, clozapine has been reported to antagonize the accumulation and the decrease in turnover rate of acetylcholine induced by the administration of oxotremorine and arecoline (Racagni et al. 1976). It has been proposed that the antimuscarinic activity of clozapine may contribute to the low incidence of extrapyramidal side effects observed in patients treated with the drug (Snyder et al. 1974; Miller and Hiley 1976).

On the other hand, there are data indicating that clozapine acts as an agonist at peripheral and central muscarinic receptors. In fact, clozapine is known to 
cause hypersalivation (Baldessarini and Frankenburg 1991), an effect blocked by antimuscarinic drugs (Lieberman et al. 1989; Fritze and Ellinger 1995). The administration of scopolamine prevented the increase in the efflux of dopamine and its metabolites elicited by clozapine in striatum of awake, freely moving rats (Rivest and Marsden 1991; Meltzer et al. 1994). In addition, Zorn et al. (1994) have shown that clozapine behaves as a full agonist at the cloned human $\mathrm{m} 4$ receptor expressed in Chinese hamster ovary $(\mathrm{CHO})$ cells, but as an antagonist at the $\mathrm{m} 1, \mathrm{~m} 2, \mathrm{~m} 3$, and $\mathrm{m} 5$ receptors. Zeng et al. (1997) reported that the ability of clozapine to activate the $\mathrm{m} 4$ muscarinic receptor is shared by a number of atypical antipsychotic drugs, suggesting that this common property could be relevant for the therapeutic efficacy and side effects of clozapine and some atypical neuroleptics.

However, we have recently found that clozapine behaves as a partial agonist at the human $\mathrm{m} 4$ receptor, rather than as a full agonist, with intrinsic activity changing as a function of the receptor density and the coupling efficiency of the receptor to effector molecules (Olianas et al. 1997). This observation raised the possibility that clozapine could also act as a partial agonist at other muscarinic receptor subtypes, providing that the receptors were expressed at sufficiently high density. To investigate this possibility, in the present study, we examined the effects of clozapine on the functional activities of the cloned human $\mathrm{m} 1, \mathrm{~m} 2$, and $\mathrm{m} 3$ receptors overexpressed in transfected $\mathrm{CHO}$ cells.

\section{MATERIALS AND METHODS}

\section{Cell Culture}

$\mathrm{CHO}$ cells expressing the human cloned $\mathrm{m} 1-\mathrm{m} 3$ receptors $(\mathrm{CHO} / \mathrm{m} 1-\mathrm{m} 3$ cells) were kindly provided by Prof. A. D. Strosberg (Institut Cochin de Genetique Moleculaire, Paris). The cells were grown as a monolayer culture in Ham's F-12 medium (GIBCO BRL) supplemented with $10 \%$ fetal calf serum in a humidified atmosphere $\left(5 \% \mathrm{CO}_{2}\right)$ at $37^{\circ} \mathrm{C}$. Cells were grown at confluency in plastic Petri dishes (Falcon).

\section{Cell Membrane Preparation}

The culture medium was removed, and the cells were washed with ice-cold phosphate-buffered saline. For radioligand binding studies, cells were homogenized in an ice-cold buffer containing $25 \mathrm{mM}$ sodium phosphate buffer ( $\mathrm{pH}$ 7.4) and $5 \mathrm{mM} \mathrm{MgCl}_{2}$ by using an Ultra-Turrax homogenizer. The cell lysate was centrifuged at $32,500 \mathrm{~g}$ for $30 \mathrm{~min}$ at $4^{\circ} \mathrm{C}$, and the pellet was resuspended in the same buffer at a protein concentration of $2.5-3.0 \mathrm{mg} / \mathrm{ml}$. The membrane preparations were either used immediately or stored at $-70^{\circ} \mathrm{C}$.
For the adenylyl cyclase assay, the cells were scraped into an ice-cold buffer containing $10 \mathrm{mM}$ HEPES/ $\mathrm{NaOH}, 1 \mathrm{mM}$ EGTA, $1 \mathrm{mM} \mathrm{MgCl}$, and $1 \mathrm{mM}$ dithiothreitol (DTT) (pH 7.4) and lysed with a Dounce tissue grinder. The cell lysate was centrifuged at $1,000 \mathrm{~g}$ for 2 min at $4^{\circ} \mathrm{C}$. The supernatant was collected and centrifuged at $32,500 \mathrm{~g}$ for $30 \mathrm{~min}$ at $4^{\circ} \mathrm{C}$. The pellet was resuspended in the homogenization buffer at a protein concentration of $\sim 2.0 \mathrm{mg} / \mathrm{ml}$ and used immediately for the enzyme assay.

\section{Assay of Adenylyl Cyclase Activity}

The enzyme activity was assayed in a reaction mixture (final volume $100 \mu \mathrm{l}$ ) containing $50 \mathrm{mM}$ HEPES/NaOH (pH 7.4), $2.3 \mathrm{mM} \mathrm{MgCl} 2,0.3 \mathrm{mM}$ EGTA, $0.05 \mathrm{mM}\left[\alpha^{-32} \mathrm{P}\right]-$ ATP (150-200 cpm/pmol), $0.5 \mathrm{mM}\left[{ }^{3} \mathrm{H}\right]$-cyclic AMP (160 $\mathrm{cpm} / \mathrm{nmol}), 50 \mu \mathrm{M}$ GTP, $1 \mathrm{mM}$ 3-isobutyl-1-methylxanthine (IBMX), $5 \mathrm{mM}$ phosphocreatine, $50 \mathrm{U} / \mathrm{ml}$ of creatine kinase, $50 \mu \mathrm{g}$ bovine serum albumin (BSA), $10 \mathrm{kal}-$ likrein inhibitor units of aprotinin, and $20 \mu \mathrm{M}$ forskolin. The incubation was started by adding the tissue preparation (30-40 $\mu \mathrm{g}$ of protein) and was carried out at $25^{\circ} \mathrm{C}$ for $20 \mathrm{~min}$. [ $\left.{ }^{32} \mathrm{P}\right]$-cyclic AMP was isolated according to Salomon et al. (1974). The recovery of $\left[{ }^{32} \mathrm{P}\right]$-cyclic AMP from each sample was corrected on the basis of the recovery of $\left[{ }^{3} \mathrm{H}\right]$-cyclic AMP.

\section{Assay of $\left[{ }^{3} \mathrm{H}\right]-$ Inositol Phosphates ([3 $\left.\left.{ }^{3} \mathrm{H}\right]-\mathrm{IPs}\right)$ Accumulation}

$\mathrm{CHO}$ cells grown in 24 well plates (Falcon) were incubated in Minimal Essential Medium (GIBCO BRL) containing $5 \mu \mathrm{Ci} / \mathrm{ml}$ of myo- $\left[{ }^{3} \mathrm{H}\right]$ inositol for $24 \mathrm{~h}$ at $37^{\circ} \mathrm{C}$ in an incubator. The medium was then removed, and the cells were incubated with oxygenated Krebs-Hepes buffer ( $\mathrm{pH}$ 7.4) containing $25 \mathrm{mM}$ HEPES/NaOH, 1.2 $\mathrm{mM} \mathrm{MgSO}_{4}, 1.2 \mathrm{mM} \mathrm{KH}_{2} \mathrm{PO}_{4}, 10 \mathrm{mM}$ glucose, $110 \mathrm{mM}$ $\mathrm{NaCl}, 3.8 \mathrm{mM} \mathrm{KCl}, 1.2 \mathrm{mM} \mathrm{CaCl}_{2}$, and $10 \mathrm{mM} \mathrm{LiCl}$. The cells were incubated for $20 \mathrm{~min}$ at $37^{\circ} \mathrm{C}$, and then carbachol (CCh), clozapine, and the appropriate vehicles were added. When used, atropine was added $20 \mathrm{~min}$ before the addition of clozapine. The incubation was continued for $40 \mathrm{~min}$ and then stopped by aspirating the medium and adding ice-cold $0.25 \mathrm{~N} \mathrm{HCl}$. After 10 min incubation at ice-bath temperature, the cells were scraped and collected in centrifuge tubes containing 1.2 $\mathrm{ml}$ of chloroform/methanol $(1: 2 \mathrm{v} / \mathrm{v})$. The samples were shaken for $10 \mathrm{~min}$ and then centrifuged at $1,000 \mathrm{~g}$ for $10 \mathrm{~min}$, the upper acqueous phase was applied to a column of Dowex $1 \times 8$ in the formate form. The column was washed with 20 bed volumes of $\mathrm{H}_{2} \mathrm{O}, 20$ bed volumes of $5 \mathrm{mM}$ myo-inositol, 16 bed volumes of $5 \mathrm{mM}$ sodium tetraborate in $60 \mathrm{mM}$ sodium formate. $\left[{ }^{3} \mathrm{H}\right]$-IPs were eluted by adding 6 bed volumes of $1 \mathrm{M}$ ammonium formate in $0.1 \mathrm{M}$ formic acid (Berridge et al. 
1983). The radioactivity present in the eluate and in the organic phase was determined by liquid scintillation counting. For each sample, the accumulation of $\left[{ }^{3} \mathrm{H}\right]-\mathrm{IPs}$ was corrected for the amount of myo- $\left[{ }^{3} \mathrm{H}\right]$ inositol incorporated in the organic phase.

\section{Assay of $\left[{ }^{3} \mathrm{H}\right]-C y c l i c$ AMP Accumulation}

$\mathrm{CHO}$ cells grown in 36-mm plastic dishes were incubated in Ham's F-12 medium containing $10 \mu \mathrm{Ci} / \mathrm{ml}$ of $\left[{ }^{3} \mathrm{H}\right]$-adenine for $1 \mathrm{~h}$ at $37^{\circ} \mathrm{C}$ in an incubator. Thereafter, the medium was removed, and the cells were incubated in an oxygenated Krebs-HEPES buffer containing $1 \mathrm{mM}$ IBMX, $25 \mu \mathrm{M}$ forskolin (FSK) and the various test compounds. After $10 \mathrm{~min}$ at $37^{\circ} \mathrm{C}$, the incubation was stopped by the aspiration of the medium and the addition of an ice-cold solution containing $6 \%(\mathrm{w} / \mathrm{v})$ perchloric acid and $0.1 \mathrm{mM}\left[{ }^{14} \mathrm{C}\right]$-cyclic AMP $(\sim 3,000 \mathrm{cpm})$. After $30 \mathrm{~min}$ at ice-bath temperature, the solution was neutralized by the addition of ice-cold $0.6 \mathrm{M} \mathrm{KOH}$ and left on ice for additional $30 \mathrm{~min}$. Following centrifugation at 15,000 $\mathrm{g}$ for $5 \mathrm{~min}$, the supernatant was collected, and $\left[{ }^{3} \mathrm{H}\right]$-cyclic AMP was isolated according to Salomon et al. (1974). The recovery of $\left[{ }^{3} \mathrm{H}\right]$-cyclic AMP from each sample was corrected on the basis of the recovery of $\left[{ }^{14} \mathrm{C}\right]$-cyclic AMP.

\section{Assay of $\left[{ }^{3} \mathrm{H}\right]-\mathrm{N}-$ Methylscopolamine ( $\left[{ }^{3} \mathrm{H}\right]-\mathrm{NMS}$ ) Binding}

The binding of $\left[{ }^{3} \mathrm{H}\right]-\mathrm{NMS}$ was assayed in a buffer containing $25 \mathrm{mM}$ sodium phosphate $(\mathrm{pH} 7.4), 5 \mathrm{mM}$ $\mathrm{MgCl}_{2}, 0.1 \% \mathrm{BSA}$, and 12-25 $\mu \mathrm{g}$ of membrane protein. The $\left[{ }^{3} \mathrm{H}\right]-\mathrm{NMS}$ concentration ranged from $20 \mathrm{pM}$ to 4.0 $\mathrm{nM}$, and the final assay volume was $1 \mathrm{ml}$. The incubation was carried out at $30^{\circ} \mathrm{C}$ for $120 \mathrm{~min}$. The incubation was stopped by adding $4 \mathrm{ml}$ of ice-cold buffer without BSA to each sample followed by immediate filtration through glass fiber filters (Whatman GF/C) presoaked in $0.1 \%$ polyethylenimine for at least $18 \mathrm{~h}$. The filters were washed twice with the same buffer, died, and the bound radioactivity was counted by liquid scintillation spectrometry. Nonspecific binding was determined in the presence of $1 \mu \mathrm{M}$ atropine.

\section{Assay of Guanosine-5'-O-(3-[ $\left.{ }^{35} \mathrm{~S}\right]-$ thio) Triphosphate ([35 $]$-GTP $\gamma \mathrm{S})$ Binding}

$\mathrm{CHO}$ cell membranes were diluted tenfold in $10 \mathrm{mM}$ HEPES/NaOH (pH 7.4), 1 mM EDTA and 0.1\% BSA, centrifuged and resuspended in the same buffer. The binding of $\left[{ }^{35} \mathrm{~S}\right]-\mathrm{GTP} \gamma \mathrm{S}$ was assayed in a reaction mixture (final volume $100 \mu \mathrm{l}$ ) containing: HEPES/NaOH (pH 7.4) $25 \mathrm{mM}, \mathrm{MgCl}_{2} 10 \mathrm{mM}$, EDTA $1 \mathrm{mM}$, GDP 1 $\mu \mathrm{M}, \mathrm{NaCl} 100 \mathrm{mM}$ and $\left[{ }^{35} \mathrm{~S}\right]-\mathrm{GTP} \gamma \mathrm{S} 2.0 \mathrm{nM}$. The incubation was started by the addition of the membrane sus- pension (3.0-5.0 $\mu \mathrm{g}$ of protein) and was carried out at $30^{\circ} \mathrm{C}$ for $60 \mathrm{~min}$. The incubation was terminated by adding $5 \mathrm{ml}$ of ice-cold buffer containing $10 \mathrm{mM}$ HEPES/ $\mathrm{NaOH}(\mathrm{pH} 7.4)$ and $1 \mathrm{mM} \mathrm{MgCl}$, immediately followed by rapid filtration through GF/C filters presoaked in the same buffer. The filters were washed twice with $5 \mathrm{ml}$ of buffer, and the radioactivity trapped was determined by liquid scintillation spectrometry. Nonspecific binding was determined in the presence of $100 \mu \mathrm{M}$ GTP $\gamma$ S. Protein content was determined by the method of Bradford (1976), using BSA as a standard.

\section{Statistical Analysis}

Results are reported as mean \pm SEM. Concentration responses curves were analyzed by a least-squares curvefitting computer program (GraphPad Prism, San Diego, CA, USA). The binding data were analyzed by the computer program EBDA, which yielded the initial estimates of equilibrium-binding parameters. These estimates were used in the nonlinear curve-fitting computer program LIGAND (Munson and Rodbard, 1980), which provided the final estimates of the dissociation constant $\left(\mathrm{K}_{\mathrm{D}}\right)$, binding capacity $\left(\mathrm{B}_{\max }\right)$ and inhibition constant $\left(\mathrm{K}_{\mathrm{i}}\right)$. Statistical significance of the difference between means was determined by Student's $t$-test.

\section{Materials}

$\left[\alpha-{ }^{32} \mathrm{P}\right]-A T P(30-40 \mathrm{Ci} / \mathrm{mmol}),\left[2,8-{ }^{3} \mathrm{H}\right]$-cyclic AMP $(25$ $\mathrm{Ci} / \mathrm{mmol}),\left[8^{-14} \mathrm{C}\right]$-cyclic AMP $(45.1 \mathrm{mCi} / \mathrm{mmol})[2.8-$ $\left.{ }^{3} \mathrm{H}\right]$-adenine $(28.8 \mathrm{Ci} / \mathrm{mmol})$ and $\left.{ }^{35} \mathrm{~S}\right] \mathrm{GTP} \gamma \mathrm{S}(1306 \mathrm{Ci} /$ $\mathrm{mmol}$ ) were obtained from New England-Du Pont (Bad Homburg, Germany). 1-[N-methyl- $\left.{ }^{3} \mathrm{H}\right]$-scopolamine methyl chloride $\left(\left[{ }^{3} \mathrm{H}\right]-\mathrm{NMS}\right)(83 \mathrm{Ci} / \mathrm{mmol})$ and myo$\left[{ }^{3} \mathrm{H}\right]$ inositol with PT6-271 stabilizer $(99 \mathrm{Ci} / \mathrm{mmol})$ were obtained from Amersham (UK).

\section{RESULTS}

\section{$\left[{ }^{3} \mathrm{H}\right]-N M S$ Binding Data}

Saturation binding experiments indicated that $\left[{ }^{3} \mathrm{H}\right]-$ $\mathrm{NMS}$ bound to $\mathrm{CHO} / \mathrm{m} 1, \mathrm{CHO} / \mathrm{m} 2$, and $\mathrm{CHO} / \mathrm{m} 3$ cell membranes with $B_{\max }$ of $11.1 \pm 0.8,3.2 \pm 0.5$, and $1.5 \pm$ $0.2 \mathrm{pmol} / \mathrm{mg}$ protein and $\mathrm{K}_{\mathrm{D}}$ values of $0.44 \pm 0.04,0.73 \pm$ 0.10 , and $0.42 \pm 0.08 \mathrm{nM}$, respectively (mean \pm SEM of three determinations). For each receptor subtype, the binding of $\left[{ }^{3} \mathrm{H}\right]-N M S$ displayed a Hill coefficient not significantly different from unity. Analysis of clozapine in competition with $\left[{ }^{3} \mathrm{H}\right]-\mathrm{NMS}$ bound to $\mathrm{m} 1, \mathrm{~m} 2$, and $\mathrm{m} 3$ receptors yielded $\mathrm{K}_{\mathrm{i}}$ values of $4.1 \pm 0.8,59.2 \pm 8.2$, and $28.0 \pm 2.1 \mathrm{nM}$, respectively. In each case, the competition curves were monophasic with Hill coefficients not different from unity. 


\section{Effects of Clozapine on [ $\left.{ }^{3} \mathrm{H}\right]-$ IPs Accumulation in $\mathrm{CHO} / \mathrm{m} 1$ and $\mathrm{CHO} / \mathrm{m} 3$ Cells}

Clozapine caused a concentration-dependent increase of $\left[{ }^{3} \mathrm{H}\right]$-IPs accumulation in $\mathrm{CHO} / \mathrm{m} 1$ cells prelabeled with myo- $\left[{ }^{3} \mathrm{H}\right]$ inositol (Figure $1 \mathrm{~A}$ ). The maximal response corresponded to a $150 \pm 13.5 \%$ increase of the basal value $(p<.01 . n=4)$ and was reached at $1 \mu \mathrm{M}$ clozapine. The concentration producing half-maximal stimulation $\left(\mathrm{EC}_{50}\right)$ was $41.9 \pm 6.3 \mathrm{nM}$. The addition of

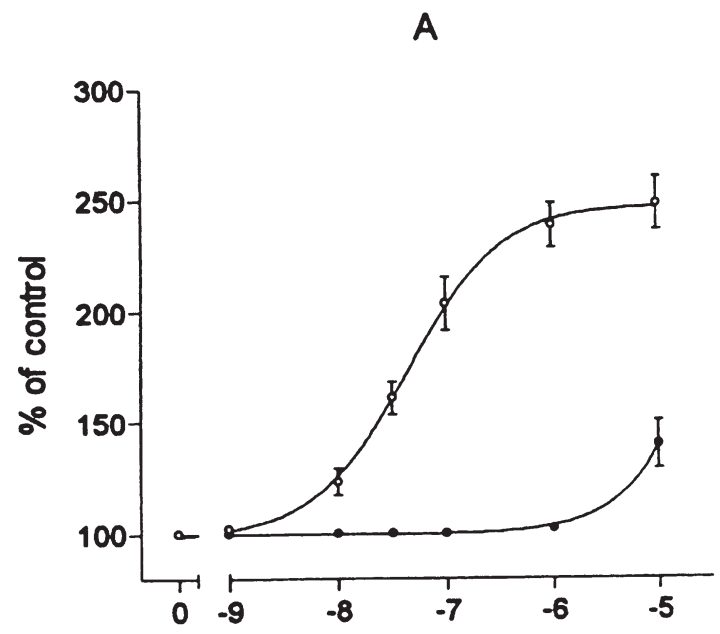

B

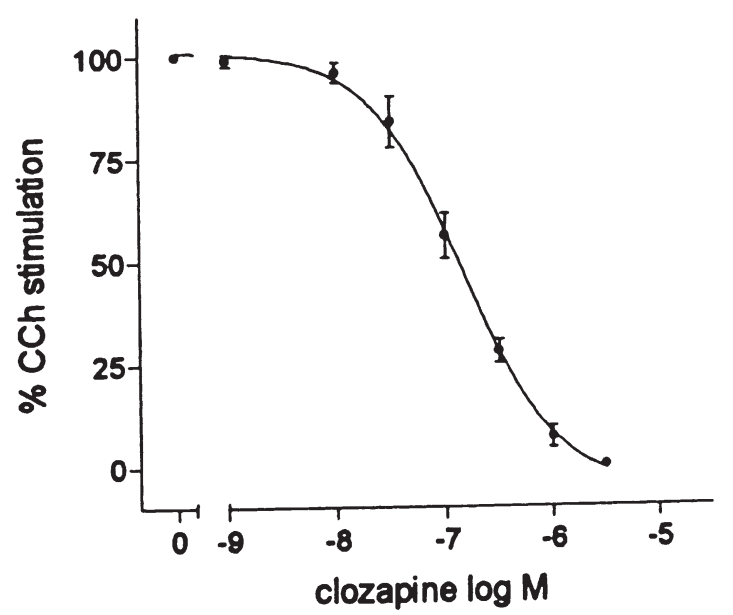

Figure 1. (A) Concentration-dependent stimulation of $\left[{ }^{3} \mathrm{H}\right]$ IPs accumulation by clozapine in $\mathrm{CHO} / \mathrm{m} 1$ cells. Cells, prelabeled with myo- $\left[{ }^{3} \mathrm{H}\right]$ inositol, were exposed to the indicated concentrations of clozapine in the absence $(\bigcirc)$ and in the presence $(0)$ of $1 \mu \mathrm{M}$ atropine. Data are the mean \pm SEM of four experiments. (B) Clozapine antagonism of carbachol (CCh)-stimulated $\left[{ }^{3} \mathrm{H}\right]$-IPs accumulation in $\mathrm{CHO} / \mathrm{m} 1$ cells. Cells were incubated with $5 \mu \mathrm{M}$ carbachol in the presence of the indicated concentrations of clozapine. The net carbachol stimulation determined at each clozapine concentration is expressed as percentage of the effect obtained in the absence of clozapine. Data are the mean \pm SEM of three experiments. the muscarinic receptor antagonist atropine $(1 \mu \mathrm{M})$ completely prevented the stimulatory effect of $1 \mu \mathrm{M}$ clozapine (Figure 1A). In a separate set of experiments, atropine was found to counteract the clozapine stimulation with a $\mathrm{K}_{\mathrm{i}}$ of $0.76 \pm 0.10 \mathrm{nM}$ (mean \pm SEM of three determinations). The full cholinergic agonist carbachol, tested at concentrations ranging from 0.1 to $100 \mu M$, maximally increased the $\left[{ }^{3} \mathrm{H}\right]-\mathrm{IPs}$ accumulation by about $9.85 \pm 0.3$-fold with an $\mathrm{EC}_{50}$ value of $360 \pm 8.9$ $\mathrm{nM}$ (mean \pm SEM of three determinations). When added together with carbachol $(5 \mu \mathrm{M})$, clozapine antagonized the stimulatory effect of the cholinergic agonist in a concentration-dependent manner (Figure 1B). The estimated $K_{1}$ value of clozapine was $9.0 \pm 1.2 \mathrm{nM}$.

Clozapine was also capable of stimulating phosphoinositide hydrolysis in $\mathrm{CHO} / \mathrm{m} 3$ cells (Figure $2 \mathrm{~A}$ ). In these cells, the drug maximally increased $\left[{ }^{3} \mathrm{H}\right]-\mathrm{IPs}$ accumulation by $34.9 \pm 4.0 \%(p<.01)$ with an $\mathrm{EC}_{50}$ value of $190 \pm 20 \mathrm{nM}$. The stimulatory effect was antagonized by the addition of $1 \mu \mathrm{M}$ atropine. Competition experiments indicated that atropine antagonized the clozapine stimulation with a $\mathrm{K}_{\mathrm{i}}$ of $1.8 \pm 0.3 \mathrm{nM}$ (mean \pm SEM of three determinations). In $\mathrm{CHO} / \mathrm{m} 3$ cells, carbachol maximally increased $\left[{ }^{3} \mathrm{H}\right]$-IPs accumulation by $23.5 \pm$ 1.8 -fold with an $\mathrm{EC}_{50}$ value of $1.6 \pm 0.4 \mu \mathrm{M}$ (mean \pm SEM of three determinations). The stimulatory effect of carbachol $(10 \mu \mathrm{M})$ was antagonized in a concentrationdependent manner by clozapine with a $\mathrm{K}_{\mathrm{i}}$ value of $50.2 \pm$ $3.8 \mathrm{nM}$ (Figure 2B).

\section{Effects of Clozapine on $\left[{ }^{3} \mathrm{H}\right] \mathrm{Cyclic}$ AMP Accumulation of $\mathrm{CHO} / \mathrm{m} 2$ Cells}

In $\mathrm{CHO} / \mathrm{m} 2$ cells prelabeled with $\left[{ }^{3} \mathrm{H}\right]$-adenine, clozapine caused a concentration-dependent inhibition of forskolinstimulated $\left[{ }^{3} \mathrm{H}\right]$ cyclic AMP accumulation (Figure 3A). The maximal inhibitory effect was reached with 3-10 $\mu \mathrm{M}$ clozapine and corresponded to a $30 \pm 2.3 \%$ reduction of control value $(p<.01)$. The $\mathrm{EC}_{50}$ value was $360 \pm$ $20 \mathrm{nM}$. The addition of $1 \mu \mathrm{M}$ atropine caused a slight but significant $(p<.05)$ increase of $\left[{ }^{3} \mathrm{H}\right]$ cyclic AMP accumulation and completely antagonized the inhibitory effect elicited by $10 \mu \mathrm{M}$ clozapine. The antagonism by atropine was concentration-dependent with a $\mathrm{K}_{\mathrm{i}}$ of $3.5 \pm 0.9$ $\mathrm{nM}$ (mean \pm SEM of three determinations) (results not shown). The assay of adenylyl cyclase activity in membranes of $\mathrm{CHO} / \mathrm{m} 2$ cells showed that clozapine maximally inhibited the forskolin-stimulated adenylyl cyclase activity by $15.5 \pm 1.4 \%$ (mean \pm SEM of three determinations, $p<.05)$ with an $\mathrm{EC}_{50}$ value of $449 \pm 29 \mathrm{nM}$. This effect was completely blocked by $1 \mu \mathrm{M}$ atropine (results not shown). Carbachol, tested at concentrations ranging from $10 \mathrm{nM}$ to $1 \mu \mathrm{M}$, maximally inhibited the forskolin-stimulated $\left[{ }^{3} \mathrm{H}\right]$ cyclic AMP accumulation by $80.9 \pm 2.9 \%$ with an $\mathrm{EC}_{50}$ value of $110.2 \pm 0.7 \mathrm{nM}$ (mean \pm SEM of three determinations). In the presence of cloza- 
A
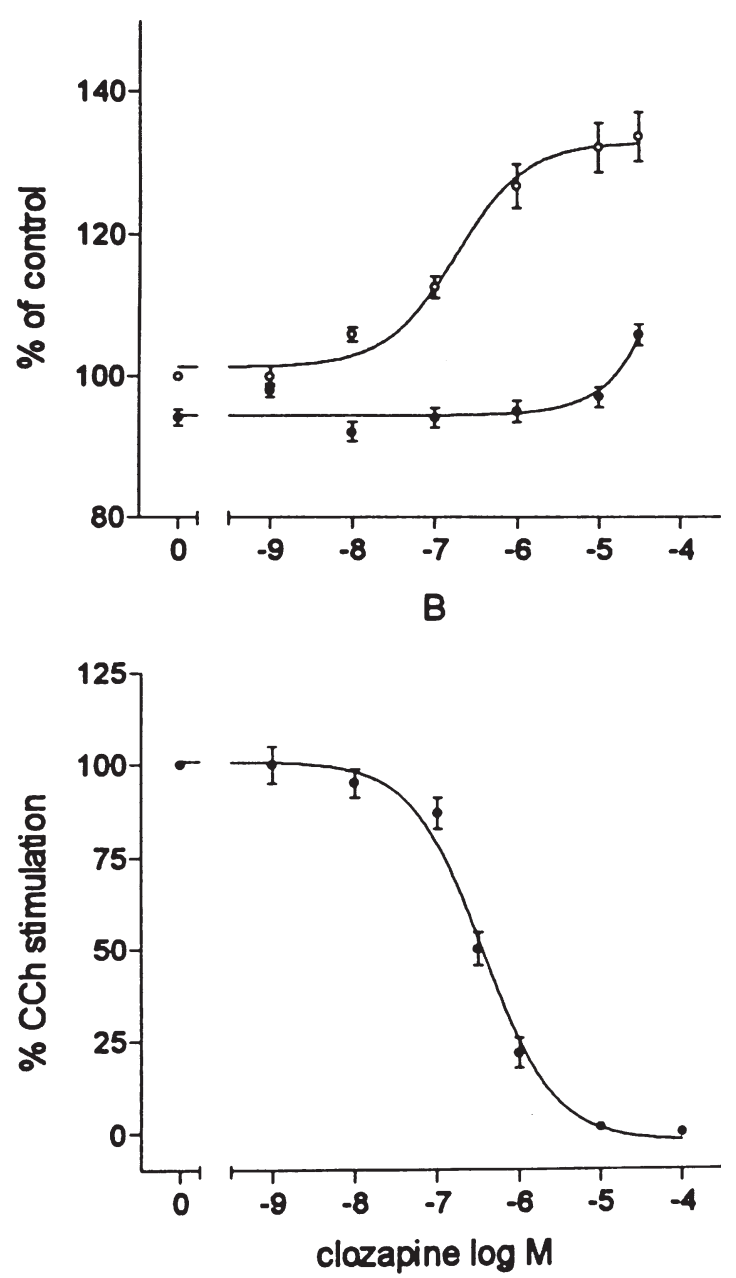

Figure 2. (A) Concentration-dependent stimulation of $\left[{ }^{3} \mathrm{H}\right]-$ IPs accumulation by clozapine in $\mathrm{CHO} / \mathrm{m} 3$ cells. Cells, prelabeled with myo- $\left[{ }^{3} \mathrm{H}\right]$ inositol, were exposed to the indicated concentrations of clozapine in the absence $(O)$ and in the presence $(-)$ of $1 \mu \mathrm{M}$ atropine. Data are the mean \pm SEM of four experiments. (B) Clozapine antagonism of carbachol (CCh)-stimulated $\left[{ }^{3} \mathrm{H}\right]-\mathrm{IPs}$ accumulation in $\mathrm{CHO} / \mathrm{m} 3$ cells. Cells were incubated with $10 \mu \mathrm{M}$ carbachol in the presence of the indicated concentrations of clozapine. The net carbachol stimulation determined at each clozapine concentration is expressed as percentage of the effect obtained in the absence of clozapine. Data are the mean \pm SEM of three experiments.

pine the cyclic AMP inhibition elicited by $1 \mu \mathrm{M}$ carbachol was reduced to the same level as that obtained with clozapine alone at maximal effective concentrations (Figure 3B). The estimated $\mathrm{K}_{\mathrm{i}}$ value of clozapine was $90.8 \pm 2.1 \mathrm{nM}$.

\section{Effects of Clozapine on $\left[{ }^{35} \mathrm{~S}\right]-\mathrm{GTP} \gamma \mathrm{S}$ Binding in $\mathrm{CHO} / \mathrm{m} 2$ Cell Membranes}

Clozapine stimulated [ $\left.{ }^{35} \mathrm{~S}\right]-\mathrm{GTP} \gamma \mathrm{S}$ binding to membrane $G$ proteins in a concentration-dependent manner with
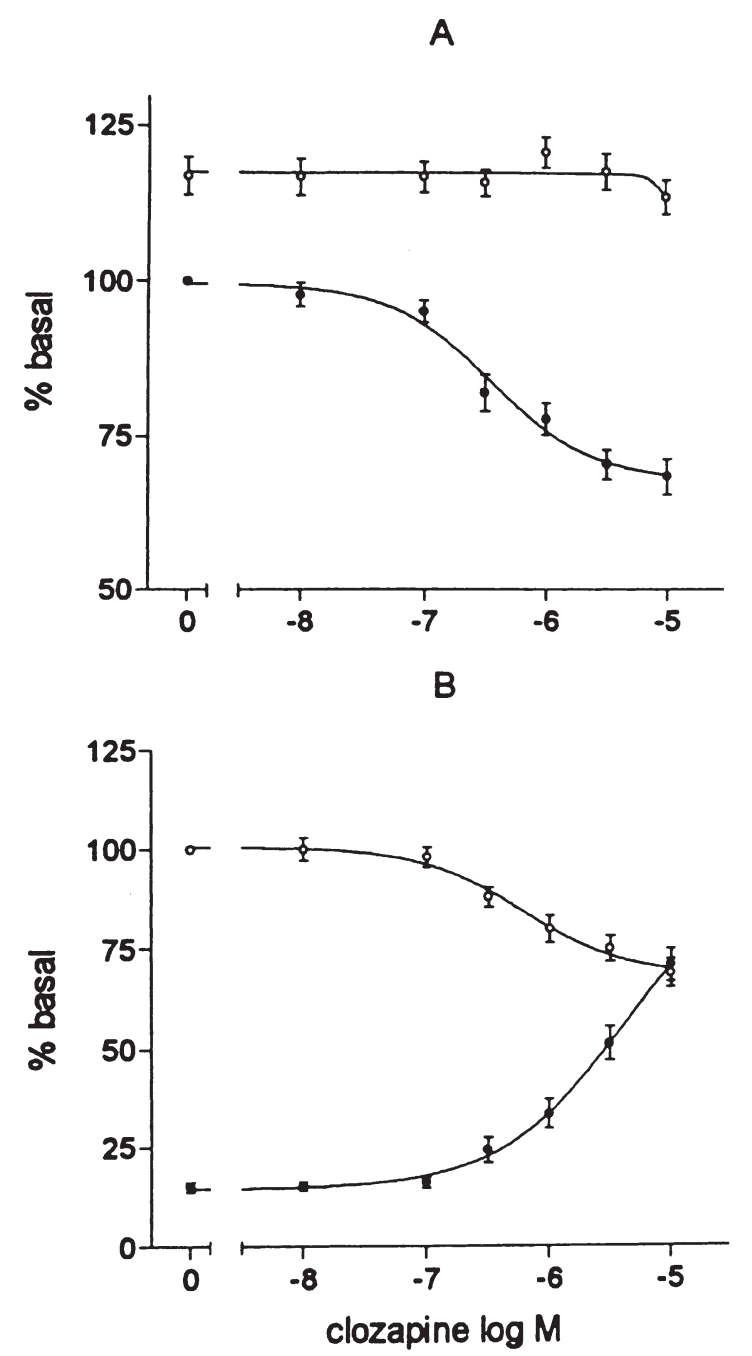

Figure 3. (A) Concentration-dependent inhibition of $\left[{ }^{3} \mathrm{H}\right]$ cyclic AMP accumulation by clozapine in $\mathrm{CHO} / \mathrm{m} 2$ cells. Cells, prelabeled with $\left[{ }^{3} \mathrm{H}\right]$-adenine, were incubated with $25 \mu \mathrm{M}$ forskolin and exposed to the indicated concentrations of clozapine in the absence $(\bullet)$ and in the presence $(\bigcirc)$ of $1 \mu \mathrm{M}$ atropine. Data are the mean \pm SEM of five experiments. (B) Clozapine antagonism of carbachol inhibition of $\left[{ }^{3} \mathrm{H}\right]$ cyclic AMP accumulation in $\mathrm{CHO} / \mathrm{m} 2$ cells. Cells were exposed to the indicated concentrations of clozapine in the absence $(O)$ and in the presence $(-)$ of $1 \mu \mathrm{M}$ carbachol. Data are the mean \pm SEM of three experiments.

an $\mathrm{EC}_{50}$ of $154 \pm 26 \mathrm{nM}$ (Figure $4 \mathrm{~A}$ ). The maximal stimulation corresponded to a $30.1 \pm 1.2 \%$ increase of control value $(p<.01)$. The effect of clozapine was completely antagonized by $1 \mu \mathrm{M}$ atropine. Competition experiments indicated that atropine antagonized the clozapine stimulation with a $\mathrm{K}_{\mathrm{i}}$ of $3.8 \pm 0.8 \mathrm{nM}$ (mean \pm SEM of three determinations). Under the same experimental conditions, $100 \mu \mathrm{M}$ carbachol maximally stimulated $\left[{ }^{35} \mathrm{~S}\right]-\mathrm{GTP} \gamma \mathrm{S}$ binding by $170 \pm 15 \%$ with an $\mathrm{EC}_{50}$ of $668 \pm 32 \mathrm{nM}$ (mean $\pm \mathrm{SEM}$ of three determinations). As reported in Figure 4B, increasing concentrations of cloz- 
A
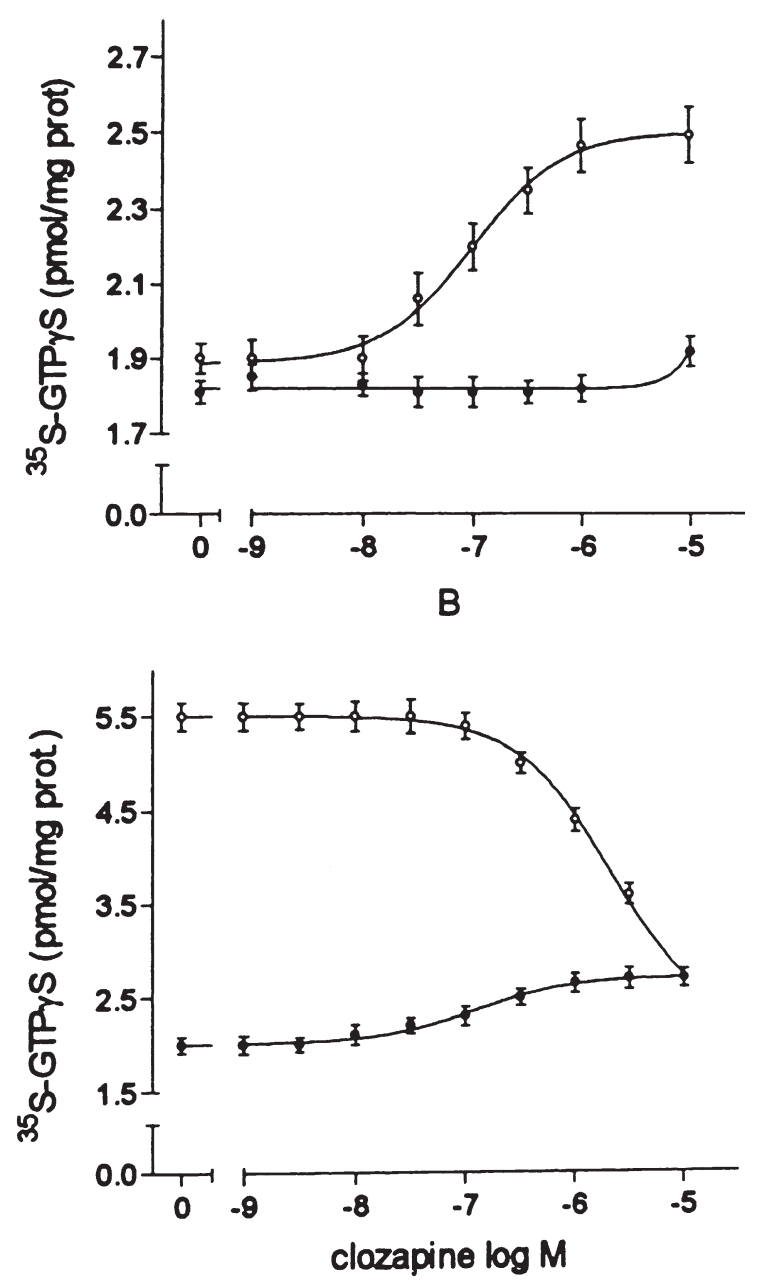

Figure 4. (A) Concentration-dependent stimulation of $\left[{ }^{35} \mathrm{~S}\right]-$ GTP $\gamma \mathrm{S}$ by clozapine in $\mathrm{CHO} / \mathrm{m} 2$ cells membranes. The specific binding of $2 \mathrm{nM}\left[{ }^{35} \mathrm{~S}\right]-\mathrm{GTP} \gamma \mathrm{S}$ was determined in membranes incubated with the indicated concentrations of clozapine in the absence $(\bigcirc)$ and in the presence $(\bullet)$ of $1 \mu \mathrm{M}$ atropine. Data are the mean \pm SEM of four experiments. (B) Clozapine antagonism of carbachol stimulation of $\left[{ }^{35} \mathrm{~S}\right]-$ GTP $\gamma \mathrm{S}$ binding. $\mathrm{CHO} / \mathrm{m} 2$ cell membranes were incubated in the presence of the indicated concentrations of clozapine without $(\bullet)$ and with $(\bigcirc) 10 \mu \mathrm{M}$ carbachol. Data are the mean \pm SEM of three experiments.

apine reduced the CCh stimulation of $\left[{ }^{35} \mathrm{~S}\right]-\mathrm{GTP} \gamma \mathrm{S}$ binding to the level determined by the clozapine maximal effect. In this experiment, the apparent $\mathrm{K}_{\mathrm{i}}$ of clozapine was $89.4 \pm 4.7 \mathrm{nM}$.

\section{DISCUSSION}

The present study shows that clozapine is capable of activating the human $\mathrm{m} 1, \mathrm{~m} 2$, and $\mathrm{m} 3$ muscarinic recep- tor subtypes expressed in $\mathrm{CHO}$ cells. The agonist properties of clozapine have been assessed by examining the coupling of the receptors to their preferential signal transduction pathways; that is, the phosphoinositides hydrolysis for the $\mathrm{m} 1$ and $\mathrm{m} 3$ and the cyclic AMP formation for the $\mathrm{m} 2$ receptor subtypes (Peralta et al. 1988). Clozapine was found to stimulate $\left[{ }^{3} \mathrm{H}\right]-\mathrm{IPs}$ accumulation in both $\mathrm{CHO} / \mathrm{m} 1$ and $\mathrm{CHO} / \mathrm{m} 3$ cells in a concentration-dependent and saturable manner. Moreover, the clozapine stimulatory effects were antagonized by atropine, demonstrating a specific action on muscarinic receptors. However, the maximal responses elicited by clozapine were much smaller than those elicited by carbachol, corresponding to about $25 \%$ and $6 \%$ of the efficacy of the full agonist in $\mathrm{CHO} / \mathrm{m} 1$ and $\mathrm{m} 3$ cells, respectively. In addition, when combined with carbachol, clozapine inhibited in a concentration-dependent manner the carbachol stimulatory effects, indicating that the drug behaved as a partial agonist.

A similar behavior was also observed in $\mathrm{CHO} / \mathrm{m} 2$ cells. In these cells, clozapine elicited a concentrationdependent inhibition of cyclic AMP accumulation that was antagonized by atropine. This finding shows that clozapine possesses the ability of stimulating the $\mathrm{m} 2$ receptor. Moreover, the response to clozapine was opposite to that elicited by atropine, which significantly increased cyclic AMP formation. This observation agrees with previous studies showing that the $\mathrm{m} 2$ receptor expressed in $\mathrm{CHO}$ and heart cells displays constitutive activity and that atropine and other muscarinic antagonists increase cyclic AMP accumulation likely by stabilizing the inactive conformation of the receptor (Jakubik et al. 1995; Vogel et al. 1995). As observed in $\mathrm{CHO} / \mathrm{m} 1$ and $\mathrm{m} 3$ cells, the agonist efficacy of clozapine at the $\mathrm{m} 2$ receptor was lower than that of the full agonist carbachol, and, when the two drugs were combined, clozapine reduced the cyclic AMP inhibition elicited by carbachol to the level determined by its maximal effect. This behavior is consistent with that of a partial agonist. We further examined the activity of clozapine at the $\mathrm{m} 2$ receptor by investigating whether the drug was capable of inducing a receptor-mediated increase of $\left[{ }^{35} \mathrm{~S}\right]-\mathrm{GTP} \gamma \mathrm{S}$ binding to membrane $\mathrm{G}$ proteins. In $\mathrm{CHO}$ cells transfected with the muscarinic receptor genes, this response has been shown to constitute a valid assay to assess the agonist and antagonist properties of different compounds (Lazareno et al. 1993). We found that clozapine stimulated [35S]-GTP $\gamma S$ binding in a concentration-dependent manner. This response was antagonized by atropine, which per se produced a slight decrease of basal [ $\left.{ }^{35} \mathrm{~S}\right]-\mathrm{GTP} \gamma \mathrm{S}$ binding.

Similarly to the other receptor-mediated responses examined, the maximal stimulation of [ $\left.{ }^{35} \mathrm{~S}\right]-\mathrm{GTP} \gamma \mathrm{S}$ binding by clozapine corresponded to a small fraction of that produced by carbachol, and the combination of the two compounds caused a reduction of the full agonist 
response to the level obtained by a maximally effective concentration of clozapine.

The data obtained using different functional receptor assays demonstrate that clozapine behaves as a partial agonist at $\mathrm{m} 1, \mathrm{~m} 2$, and $\mathrm{m} 3$ muscarinic receptor subtypes. This observation complements our previous study showing that clozapine displays partial agonist properties at the $\mathrm{m} 4$ receptor subtype (Olianas et al. 1997). Thus, clozapine-induced partial receptor activation seems to be a common phenomenon at m1-m4 muscarinic receptor subtypes. Our data differ from those reported by Zorn et al. (1994), who reported that clozapine is a full and selective $\mathrm{m} 4$ agonist and an antagonist of the $\mathrm{m} 1, \mathrm{~m} 2, \mathrm{~m} 3$, and $\mathrm{m} 5$ muscarinic receptor subtypes. The reason for this discrepancy is not known. However, because the intrinsic activity of partial agonists depends upon receptor density (Kenakin 1987), a possible explanation may be that in the study of Zorn et al. the level of expression of $\mathrm{m} 1, \mathrm{~m} 2$, and $\mathrm{m} 3$ receptors by $\mathrm{CHO}$ cells was not sufficiently high to allow the detection of the clozapine agonist effects.

In radioligand binding experiments, clozapine was found to compete with $\left[{ }^{3} \mathrm{H}\right]-\mathrm{NMS}$ with $\mathrm{K}_{\mathrm{i}}$ values of 4.1, 59.2 , and $28 \mathrm{nM}$ for the $\mathrm{m} 1, \mathrm{~m} 2$, and $\mathrm{m} 3$ receptors, respectively. These values were similar to those previously reported by other investigators (Bolden et al. 1992). The binding values were also close to the estimated potencies of clozapine in counteracting the carbachol effects at $\mathrm{m} 1$ $\left(\mathrm{K}_{\mathrm{i}}=9 \mathrm{nM}\right), \mathrm{m} 2\left(\mathrm{~K}_{\mathrm{i}}=\sim 90.0 \mathrm{nM}\right)$, and $\mathrm{m} 3\left(\mathrm{~K}_{\mathrm{i}}=50.2 \mathrm{nM}\right)$ receptors. Conversely, the $\mathrm{EC}_{50}$ values of clozapine (41 at $\mathrm{m} 1,154-360$ and $\mathrm{m} 2$, and $190 \mathrm{nM}$ at $\mathrm{m} 3$ receptors) were several-fold higher than the binding affinities. This suggests that clozapine required the occupancy of a large fraction of receptor to elicit agonist responses.

The demonstration that clozapine acts as a partial agonist at muscarinic receptors may help to explain some previously noted discrepancies between the pharmacological effects of clozapine and those of pure muscarinic antagonists, such as atropine and scopolamine. For example, chronic treatment with clozapine failed to cause an increase in $\mathrm{M}_{1}$ and $\mathrm{M}_{2}$ muscarinic receptor densities in rat striatum; whereas, repeated administration of atropine produced a significant increase (Cawley et al. 1993). Clozapine, but not scopolamine or atropine, was found to increase the efflux of dopamine and its metabolites in rat striatum (Rivest and Marsden 1991; Meltzer et al. 1994). The clozapine effect was blocked by the administration of either atropine or scopolamine. Moreover, concurrent anticholinergic therapy worsen neuroleptic-induced tardive dyskinesia (Barnes and McPhillips 1996); whereas, clozapine displays a low propensity to induce tardive dyskinesia and may even be beneficial in this disorder (Casey 1989; Lieberman et al. 1991; Gerlach et al. 1996).

A number of neurotransmitter receptor systems have been proposed to be involved in the antipsychotic activity of clozapine, including the dopamine $\mathrm{D}_{2}$ and $\mathrm{D}_{4}$, the serotonin $5-\mathrm{HT}_{2 \mathrm{~A}}$ and $5-\mathrm{HT}_{2 \mathrm{C}}$, and the glutamate receptors (Ashby and Wang, 1996). It is possible that the muscarinic partial agonist activity also contributes to the antipsychotic profile of clozapine, a drug effective in treating both positive and negative symptoms of schizophrenia (Meltzer, 1995). Indeed, there are reports that the stimulation of central muscarinic receptors has beneficial effects in schizophrenia, especially on positive symptoms refractory to conventional treatment (Pfeiffer and Jenney 1957; Rosenthal and Bigelow 1973). The intrinsic muscarinic activity of clozapine may contribute to the clinical utility of the drug in improving this symptomatology. On the other hand, the ability of clozapine to curtail the full muscarinic receptor activation may be relevant for the therapeutic efficacy of the drug in treating the negative symptoms, which have been associated with an overactivity of the central cholinergic system (Tandon et al. 1992).

\section{ACKNOWLEDGMENTS}

We are grateful to Prof. A. D. Strosberg, Institut Cochin de Genetique Moleculaire, Paris, for the generous gift of $\mathrm{CHO}$ cells transfected with the muscarinic receptor genes. This work was supported by grant CHRXCT940689 from the European communities to PO and by MURST.

\section{REFERENCES}

Ashby CR Jr, Wang RY (1996): Pharmacological actions of the atypical antipsychotic drug clozapine: A review. Synapse 24:349-394

Baldessarini RJ, Frankenburg FR (1991): Clozapine: A novel antipsychotic agent. New Engl J Med 324:746-754

Barnes TRE, McPhillips MA (1996): Antipsychotic-induced extrapyramidal symptoms. Role of anticholinergic drugs in treatment. CNS Drugs 6:315-330

Berridge MJ, Dawson RMC, Downes CP, Heslop JP, Irvine RF (1983): Changes in the levels of inositol phosphates after agonist-dependent hydrolysis of membrane phosphoinositides. Biochem J 212:473-482

Bolden C, Cusack B, Richelson E (1992): Antagonism by antimuscarinic and neuroleptic compounds at the five cloned human muscarinic cholinergic receptors expressed in Chinese hamster ovary cells. J Pharmacol Exp Ther 260:576-580

Bradford MM (1976): A rapid and sensitive method for the quantitation of microgram quantities of protein utilizing the principle of protein-dye binding. Anal Biochem 72:248-254

Casey DE (1989): Clozapine: Neuroleptic-induced EPS and tardive dyskinesia. Psychopharmacology 99:S47-S53

Cawley TA, Shickley TJ, Ruggeri MR, Luthin GR (1993): Effect of chronic neuroleptic treatment on central and peripheral muscarinic receptors. J Pharmacol Exp Ther 267:134-139 
Fjalland B, Christensen AV, Hyttel J (1977): Peripheral and central muscarinic receptor affinity of psychotropic drugs. Naunyn-Schmiedeberg's Arch Pharmacol 301:5-9

Fritze J, Ellinger T (1995): Pirenzepine for clozapine-induced hypersalivation. Lancet 346:1034

Gerlach J, Lublin H, Peacock L (1996): Extrapyramidal symptoms during long-term treatment with antipsychotics. Neuropsychopharmacology 14:35S-39S

Herrling PL, Misbach-Lesenne B (1982): Effects of clozapine in a selective muscarinic bioassay and on single cells of the rat hippocampus. Naunyn-Schmiedeberg's Arch Pharmacol 320:20-25

Jakubik J, Bacakova L, El-Fakahany EE, Tucek S (1995): Constitutive activity of the $\mathrm{M}_{1}-\mathrm{M}_{4}$ subtypes of muscarinic receptors in transfected $\mathrm{CHO}$ cells and of muscarinic receptors in the heart cells revealed by negative antagonists. FEBS Lett 377:275-279

Kenakin TP (1987): Pharmacologic Analysis of Drug-Receptor Interaction. New York, Raven Press

Lazareno S, Farries T, Birdsall NJM (1993): Pharmacological characterization of guanine nucleotide exchange reactions in membranes from $\mathrm{CHO}$ cells stably transfected with human muscarinic receptors M1-M4. Life Sci 52: $449-456$

Lieberman JA, Kane JM, Johns CA (1989): Clozapine: Guidelines for clinical management. J Clin Psychiatr 50:329338

Lieberman JA, Saltz BL, Johns CA, Pollack S, Borenstein M, Kane J (1991): The effects of clozapine on tardive dyskinesia. Br J Psychiatr 158:503-510

Meltzer HY (1995): Atypical antipsychotic drugs. In Bloom EF, Kupfer DJ (eds), Psychopharmacology: The Fourth Generation of Progress. New York, Raven Press, pp 1277-1286

Meltzer HY, Chai BL, Thompson PA, Yamamoto BK (1994): Effect of scopolamine on the efflux of dopamine and its metabolites after clozapine, haloperidol or thioridazine. J Pharmacol Exp Ther 268:1452-1461

Miller RJ, Hiley CR (1974): Antimuscarinic properties of neuroleptics and drug-induced parkinsonism. Nature 268: 596-597

Miller RJ, Hiley CR (1976): Anti-dopaminergic and anti-muscarinic effects of dibenzodiazepines: Relationship to drug-induced parkinsonism. Naunyn-Schmiedelberg's Arch Pharmacol 292:289-293

Munson PJ, Rodbard D (1980): LIGAND: A versatile computerized approach for the characterization of ligandbinding systems. Anal Biochem 107:220-239

Niemegeers CJE, Awouters F, Lenaerts FM, Vermeire J, Jans- sen PAJ (1982): Prevention of physostigmine-induced lethality in rats. A pharmacological analysis. Arch Int Pharmacodyn 259:153-165

Olianas MC, Maullu C, Onali P (1997): Effects of clozapine on rat striatal muscarinic receptors coupled to inhibition of adenylyl cyclase activity and on the human cloned $\mathrm{m} 4$ receptor. Br J Pharmacol 122:401-408

Peralta EG, Ashkenazi A, Winslow JW, Smith DH, Ramachandran J, Capon DJ (1988): Differential regulation of Pi hydrolysis and adenylyl cyclase by muscarinic receptor subtypes. Nature 334:434-437

Pfeiffer CC, Jenney EH (1957): Inhibition of the conditioned response and the counteraction of schizophrenia by muscarinic stimulation of the brain. Ann NY Acad Sci 66:753-764

Racagni G, Cheney DL, Trabucchi M, Costa E (1976): In vivo actions of clozapine and haloperidol on the turnover rate of acetylcholine in rat striatum. J Pharmacol Exp Ther 196:323-332

Rivest R, Marsden CA (1991): Muscarinic antagonists attenuate the increase in accumbens and striatum dopamine metabolism produced by clozapine but not by haloperidol. Br J Pharmacol 104:234-238

Rosenthal R, Bigelow LB (1973): The effects of physostigmine in phenothiazine resistant chronic schizophrenic patients: Preliminary observations. Comp Psychiatr 14: 489-494

Salomon Y, Londos D, Rodbell M (1974): A highly sensitive adenylate cyclase assay. Anal Biochem 58:541-548

Sayers AC, Burki HR (1976): Antiacetylcholine activities of psychoactive drugs: A comparison of the $\left[{ }^{3} \mathrm{H}\right]$ quinuclidinyl benzilate binding assay with conventional methods. J Pharm Pharmacol 28:252-253

Snyder SH, Greenberg D, Yamamura HI (1974): Antischizophrenic drugs and brain cholinergic receptors. Arch Gen Psychiatr 31:58-61

Tandon R, DeQuardo JR, Goodson J-A, Mann NA, Greden JF (1992): Effect of anticholinergics on positive and negative symptoms in schizophrenia. Psycopharmacol Bull 28:297-302

Vogel WK, Mosser VA, Bulseco DA, Schimerlik MI (1995): Porcine $\mathrm{m} 2$ muscarinic acetylcholine receptor-effector coupling in Chinese hamster ovary cells. J Biol Chem 270:15485-15493

Zeng XP, Le F, Richelson E (1997): Muscarinic m4 receptor activation by some atypical antipsychotic drugs. Eur J Pharmacol 321:349-354

Zorn SH, Jones SB, Ward KM, Liston DR (1994): Clozapine is a potent and selective muscarinic $\mathrm{m}_{4}$ receptor agonist. Eur J Pharmacol-Mol Pharmacol Sect 269:R1-R2 